\title{
8. Household debt: supply-driven sugar rushes
}

\section{Maria Teresa Punzi ${ }^{1}$}

\section{INTRODUCTION}

In many Asian economies, household debt as measured by the household debt-to-gross domestic product (GDP) ratio has been escalating for two decades. The process worsened after the 2008-2009 global financial crisis (GFC) that originated in the United States (US). The GFC was triggered by the inherent vulnerabilities of the financial system which spilled over into the real economy. As a consequence, the household debt-to-GDP ratio expanded at an even faster pace, primarily driven by loans to purchase residential properties. More recently, household debt-to-GDP ratio increased further since the onset of the COVID-19 crisis in 2020. Many economies have been experiencing unfavorable economic conditions and slow growth of disposable income, which are affecting household balance sheets and household incomes.

The shock from the pandemic shares both similarities and differences with the 2008-2009 GFC. While the GFC was rooted in a weak financial system, which allowed households with low credit scores to obtain mortgage loans, the COVID-19 pandemic is rooted in a widespread health crisis, which has led governments to impose measures to contain the spread of the virus such as prolonged lockdowns, causing adverse shocks to the real economy. Many households were pushed to borrow more to mitigate the severe economic downturn. In addition, lower working hours, furloughs, and outright unemployment have limited the capacity of households to service their outstanding debts. The COVID-19 crisis has brought households to the brink of bankruptcy as they suffer from debt distress in the face of the economic slowdown, adding extra costs and credit risk to the pre-existing vulnerabilities of large household debt.

In general, an increase in household debt is not necessarily a reason for concern. Household debt can stimulate long-term investment: households taking out credit are essential to a growing economy as they smooth out consumption and invest in illiquid assets, such as dwellings, thus boosting the economy. However, household debt has also been shown to increase the risk of low economic growth over the medium term. Taking a mixed sample of 30 advanced and emerging economies, Mian et al. (2017) found a 0.4 percent decline in economic growth after seven years following an initial two-year increase. Based on a sample of 80 economies, the International Monetary Fund (IMF) also found that a 5 percent increase in the household debt-to-GDP ratio would lead to a 1.25 percent decline in real GDP over a three-year horizon, as the resulting debt burden slows economic growth. Debt can also make the economy more vulnerable to economic shocks, because by investing their debt in the long term (for education and housing, for example), households will have insufficient funds to handle emergencies. Zabai (2017) found that due to this trade-off between short-term growth 
and long-term vulnerability, household debt may threaten both macroeconomic and financial stabilities. Adverse shocks have a negative impact on households' ability (or willingness) to pay their debts, producing a strong negative impact on the financial health of lenders. This may either trigger or deepen or lengthen economic recession. As a result, household debt may amplify cyclical downturns and weaken economic recovery (Leigh et al. 2012).

The household debt-to-GDP ratio and its increase are not sufficient indicators of financial instability, however. By the end of 2007, right before the GFC, the household debt-to-GDP ratio of the US stood at 99 percent, with an increase of about 28 percentage points (pp) since 2000, which could lead us to conclude that a ratio of this magnitude is unsustainable, and that economies with a household debt-to-GDP ratio higher than 90 percent should be considered beyond the alarm threshold. Indeed, this high ratio of debt, if confronted with an economic shock, such as a GFC, may lead to disastrous consequences for the economy, or even a recession, as people lack sufficient liquid assets to survive the crisis. The GFC has shown that income and wealth shocks get amplified by high levels of household debt and, in the case of negative shocks, a spending cut occurs mainly across highly indebted households, rather than the non-indebted ones. ${ }^{2}$ This creates an inherent fragility of the economic system. Unpredictable events such as the current COVID-19 pandemic, which bring about unexpected and sudden reductions of households' income, could lead to two outcomes: (1) households could try to take out more loans to finance current consumption, piling up more debt and further compromising future stability; or (2) households could miss or postpone their monthly repayment, generating immediate stress on the banking sector.

Schularick and Taylor (2012) showed that a rapid growth of credit can trigger financial instability, as increasingly more disposable income will be directed toward debt service, raising concerns about sustainability. Cecchetti et al. (2011) also found that a household debt-to-GDP ratio exceeding a threshold value of around 85 percent would negatively affect economic growth, but Australia, Denmark, and the Netherlands have not experienced major financial crises even though their ratios stood at 110 percent, 124 percent, and 110 percent, respectively, as of $2007 .{ }^{3}$

As the correlation between the household debt-to-GDP ratio and the likelihood of a financial crisis may not be robust, other factors should be taken into account to determine the extent to which rapid household debt accumulation poses risks to the stability of the economic and financial system. These include the composition of debt, which affects how resilient each debt is to shocks and determines the likelihood of default and the extent to which household debt servicing capacity is supported by adequate financial buffers and income growth.

To determine how best to address the problem of rising debt, it is necessary to evaluate whether the run-up in household debt is mostly driven by demand or supply factors. ${ }^{4}$ The sharp increase in the household debt-to-GDP ratio is often considered to be an outcome of credit demand shocks pushing constrained households to borrow more. Indeed, the presence of a collateral value is amplified as the housing market expands and contracts. ${ }^{5}$ However, recent studies have found that credit supply shocks also play an important role in explaining the rise in household debt. Banking deregulations, behavioral factors, or simply a willingness to lend more make more credit available for households. It is important to understand and identify the nature of shocks, as demand or supply will have different implications. Credit demand boosts households' consumption, which in turn shifts aggregate demand. Credit supply, however, shifts aggregate supply, which has a deflation effect relative to the demand side. Nevertheless, 
if the expansion in household debt is mostly driven by supply shocks, without an equal expansion in income, then too rapid or too large a debt buildup will trigger financial instability and economic recession.

Against this background, we develop different approaches to assess the sustainability of household debt in Asia. First, we identify whether the surge in household debt is supply- or demand-driven by comparing the effects of household debt and nonfinancial corporate debt on real GDP. A panel regression analysis based on nine Asian economies shows that a $1 \mathrm{pp}$ increase in the ratio of household debt increases real GDP by 0.5 percent, but this positive effect is reversed after seven years, with a decline of 1.5 percent. We also find that supply shocks have been driven by the large expansion in household debt. Indeed, relaxation of lending constraints and deregulation of the banking sector have made possible the supply of credit at low interest rates, which can be unsustainable for two reasons: (1) credit issued during periods of low interest rates could flow toward households with lower credit quality, causing risk of default in the future; and (2) if household debt is driven by supply shocks rather than demand shocks, then the debt expansion is not associated to an equal expansion in income, causing risk of default during cases of overoptimism about future income.

Second, to assess the vulnerability of households to COVID-19 shocks - such as a sudden decrease in income due to lower working hours, furloughs, and unemployment-we analyze how adverse shocks would affect each household's debt-repayment ability. Based on their income level, we identified households with excessive debt levels and weak financial soundness to assess how vulnerable these groups are to the occurrence of external shocks.

Results indicate that in the People's Republic of China (PRC) and the Republic of Korea (ROK), the bottom 20 percent of households by income distribution are most likely to default on their mortgages after a 10 percent decline in disposable income. However, while the probability of default for the upper-income households is marginal in the ROK, a higher probability of default for all income groups is shown in the PRC, even if the probability decreases in the higher-income group.

The results of this analysis show that although the household debt burden might sound sustainable at the macro level, debt distribution by income group matters for financial vulnerability. Lockdown disrupts household income, which decreases the ability of low-income households to service their debt obligations and increases the probability of default. This condition gradually causes foreclosure of the collateral for secure debts, exposing lenders to a high risk of bankruptcy. Because of their higher risk of default, lower-income borrowers pose additional risks and are more likely to exacerbate the economic downturn caused during the COVID-19 crisis and increase the vulnerability of the whole financial system.

This chapter is organized as follows: section 2 presents the stylized facts for nine Asian economies (the PRC; Hong Kong, China; India; Indonesia; Japan; the ROK; Malaysia; Singapore; and Thailand) to monitor the relationship between household debt in each economy and other economic indicators from 2010 to 2019. Section 3 estimates a panel vector autoregression (VAR) model to assess the short- and medium-term impact of household debt on GDP. It also develops a macro stress test to evaluate the household debt vulnerability to negative shocks. Section 4 discusses policy responses. Section 5 concludes and discusses policy recommendations. 


\section{STYLIZED FACTS}

This chapter analyzes the reason for and implications of household debt trends in conjunction with other economic measures and macro-financial linkages. To best monitor these linkages, we analyze the evolution of a number of indicators during 2010-2019, following the GFC. We choose this sample period because since the crisis many economies have expanded their policy toolkits to make future financial crises less likely or less severe. The analysis provides an insight into the effects of such policies. Interestingly, emerging economies have been primarily responsible for the buildup of global private debt over this period, with a few Asian economies experiencing the largest increases. This raises concerns about the effectiveness of implemented risk mitigation policies.

The level of household debt in Asian economies is a concern due to its relatively large size, high growth rate, and quality, because an unanticipated deterioration in market conditions or household economic circumstances can affect a household's ability to service its debt obligations. The PRC has witnessed the most rapid growth in the household debt-to-GDP ratio, rising from 27 percent in 2010 to 56 percent in 2019 (Table 8.1). The ratio of its household debt to disposable income was around 90 percent in 2018 compared with 31 percent in 2008. After rising by 28 percent during 2010-2019, the ratio of household debt to GDP reached 96 percent in the ROK, followed closely by Hong Kong, China-where the ratio grew by 37 percent during the same period-Singapore, Malaysia, and Thailand, although the latter two economies have seen a declining ratio in recent years as a result of the implementation of measures such as tightened regulations on unsecured consumer lending (Figure 8.1). India and Indonesia have the lowest household debt-to-GDP ratios, ranging from around 12 percent to 17 percent. At a constant 17 percent, Indonesia's ratio has remained stable throughout the last five years. 


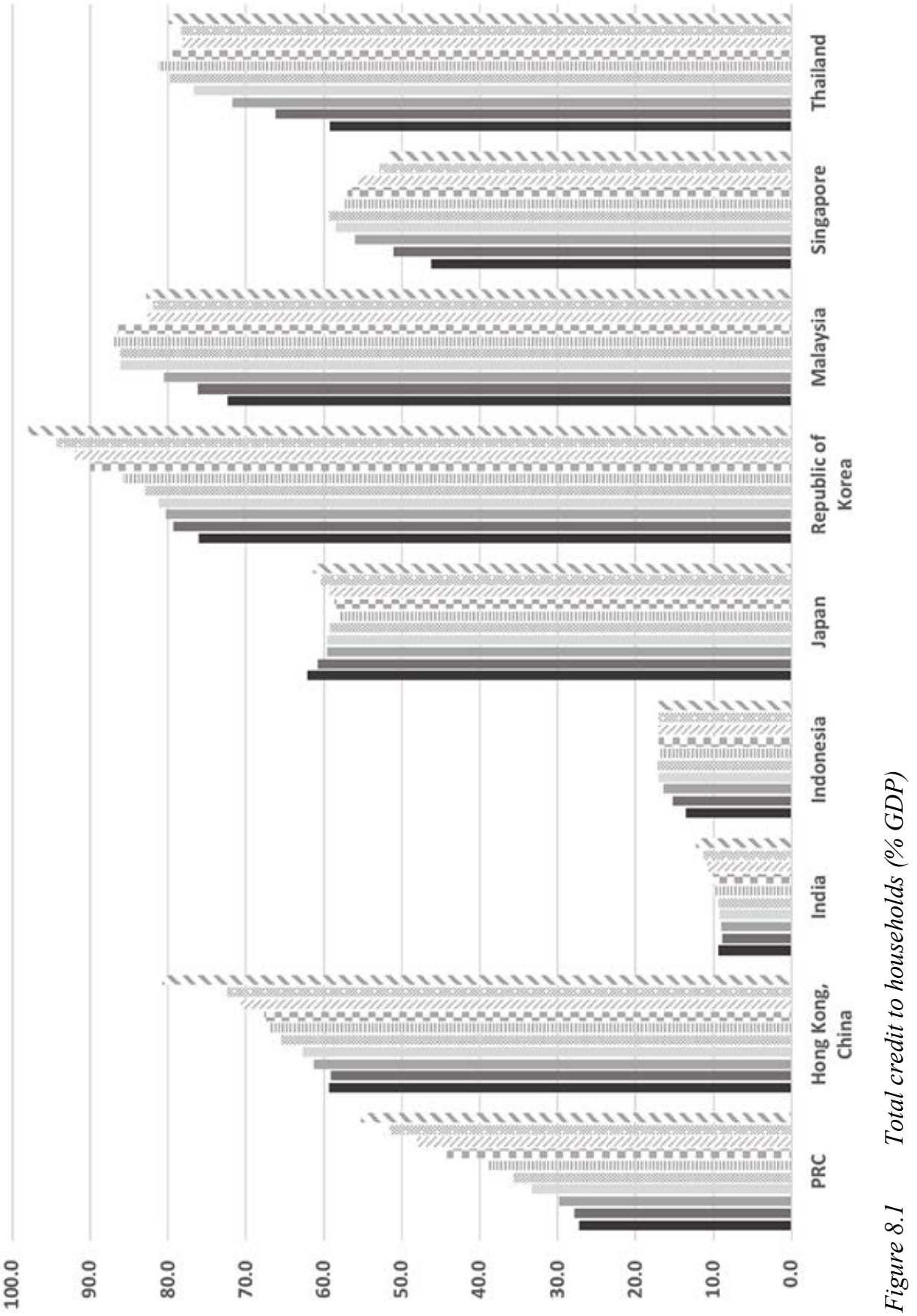


Table $8.1 \quad$ Household credit-to-GDP ratio

\begin{tabular}{|c|c|c|c|c|c|c|c|}
\hline Economy & 2010 & 2019 & $\begin{array}{r}\text { Changes } \\
(\% \mathrm{p})\end{array}$ & Economy & 2010 & 2019 & $\begin{array}{r}\text { Changes } \\
(\% \mathrm{p})\end{array}$ \\
\hline Australia & 112 & 120 & 8 & Republic of Korea & 76 & 98 & 22 \\
\hline New Zealand & 90 & 94 & 4 & Hong Kong, China & 59 & 81 & 22 \\
\hline United Kingdom & 92 & 84 & -8 & Thailand & 59 & 80 & 21 \\
\hline United States & 92 & 75 & -17 & Malaysia & 72 & 83 & 10 \\
\hline Euro area & 64 & 58 & -6 & Japan & 62 & 61 & -1 \\
\hline G20 (aggregate) ${ }^{\mathrm{a}}$ & 63 & 61 & -2 & PRC & 27 & 56 & 29 \\
\hline Advanced economies ${ }^{\mathrm{a}}$ & 81 & 74 & -7 & Singapore & 46 & 52 & 6 \\
\hline $\begin{array}{l}\text { Emerging market } \\
\text { economies }^{\mathrm{a}}\end{array}$ & 27 & 43 & 16 & Indonesia & 14 & 17 & 3 \\
\hline $\begin{array}{l}\text { All reporting } \\
\text { economies }^{\mathrm{a}}\end{array}$ & 64 & 62 & -2 & India & 9 & 12 & 3 \\
\hline
\end{tabular}

Notes:

$\mathrm{BIS}=$ Bank for International Settlements; GDP = gross domestic product; $\% \mathrm{p}=$ percentage point $(\mathrm{pp}) ; \mathrm{PRC}=$ People's Republic of China.

a Aggregates based on conversion to US dollars at market exchange rates.

Sources: CEIC database and BIS Statistics.

It is worth comparing Asia's emerging economies with the rest of the world (Table 8.1). Advanced economies like the US and the United Kingdom (UK) display some of the biggest decreases, at 17 percent and 8 percent, respectively. Of the Asian economies, only Japan has a slight decrease of 1 percent. As a comparison, advanced economies average out to a 7 percent decrease while emerging economies have a significant average increase of 16 percent.

Asia's high increase in household debt might be associated with and may have even contributed to the rapid growth of Asian economies, as economies take on debt in order to invest. However, for most Asian economies, household credit growth is larger than the growth rate of GDP and total credit, except for Hong Kong, China and Indonesia (Figure 8.2).

A closer look at the PRC reveals that the real per-capita disposable income grew 6.1 percent in 2019, down from 6.5 percent and 7.3 percent in 2018 and 2017, respectively. Moreover, the charges on household debt service to disposable income accounted for about 7 percent, 8 percent, and 11 percent in 2011, 2015, and 2017, respectively, proving that more income is directed toward debt repayments.

An important indicator of financial stability is the Basel Credit Gap as a percentage of GDP, which measures the deviation of the credit-to-GDP ratio from its long-term trend (Baba et al. 2020). Figure 8.3 reports the values of this index, which are estimated with a one-sided Hodrick-Prescott (HP) filter. The Basel Credit Gap shows a downward trend in all the sample economies since 2015, except in Japan where the gap has been rising rapidly, signaling a growing risk of financial crisis. The Gap has started to grow in India, but it is still negative ( -7 percent), as it is in the PRC - meaning that credit-to-GDP is still lower than the long-term expected value in these two economies.

Last, we consider the real house price index (RHPI) fluctuations from 2010 to 2019, with the benchmark level in 2010 set at 100 . This index is used to measure and compare residential 
housing prices and predict future changes in the prices, as increasing prices stimulate housing demand as an alternative form of investment, causing a further increase in the prices.
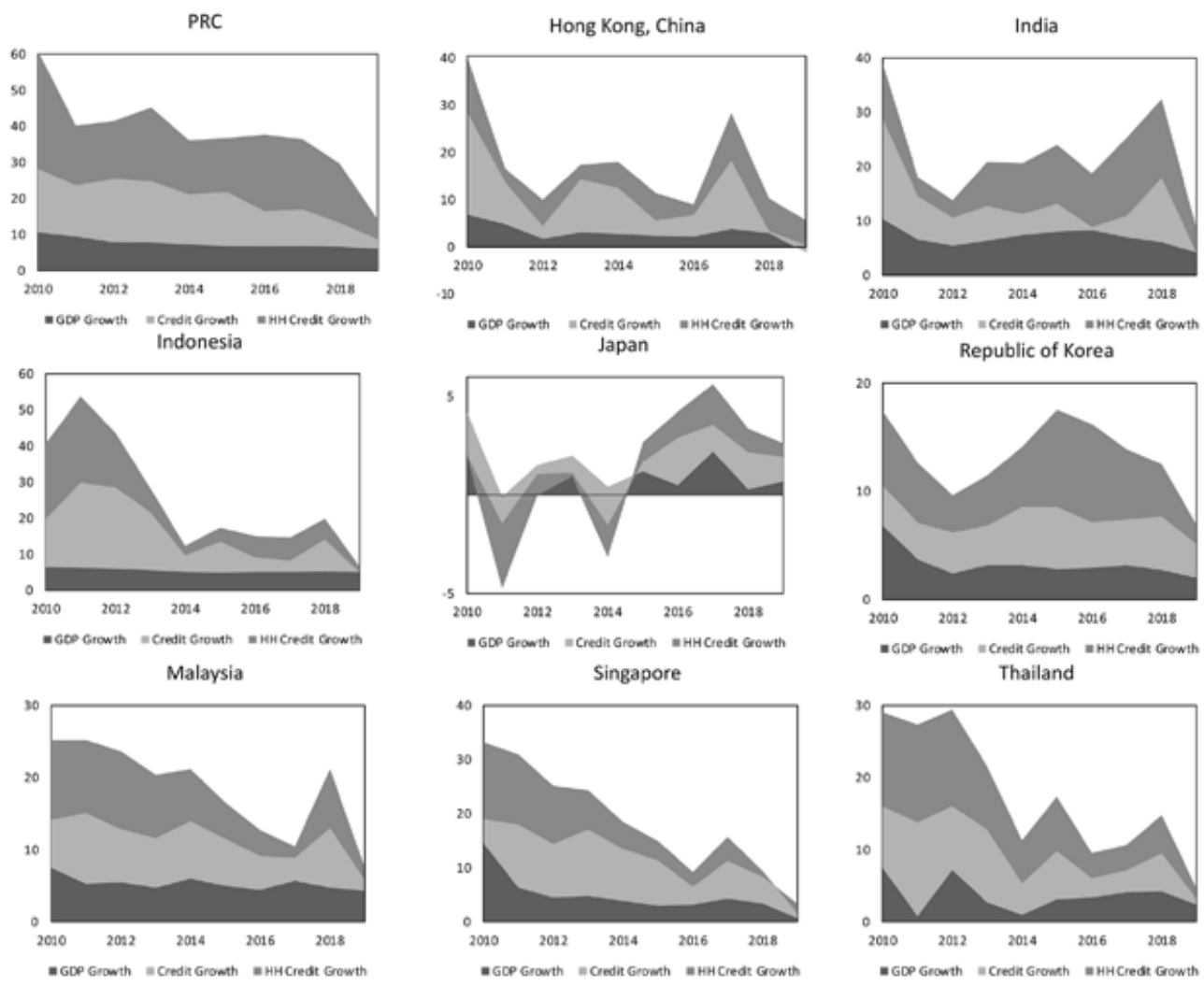

Note $:$ BIS = Bank for International Settlements; GDP = gross domestic product; HH = households; PRC $=$ People's Republic of China.

Source: BIS Statistics.

\section{Figure 8.2 Growth rates (\%)}

In recent years, the RHPI in Indonesia, India, and Malaysia has shown an upward trend (Figure 8.4). That can mean that these economies' property prices have increased compared with 2010, increasing the risk of default, as the value of a house can fall below the mortgage balance if the bubble bursts, leading to default if the borrower does not have sufficient income to service its mortgage. The lowest fluctuations in RHPI occur in Indonesia, the ROK, Japan, and Singapore, suggesting that residential housing prices in those economies have remained relatively stable, reducing the risk of mortgage defaults.

The low interest rate environment and the surge in household debt have clearly led to a large run-up in house prices in Asia. Household borrowing is strongly correlated with house prices, with a strong co-movement over time. Subsequently, we may expect house prices to fall during 
the COVID-19 recession, as households facing financial stress may put their home up for sale to survive the dramatic effect of the lockdowns. Moreover, these households would be likely to cut their spending, exacerbating the economic downturn even further.
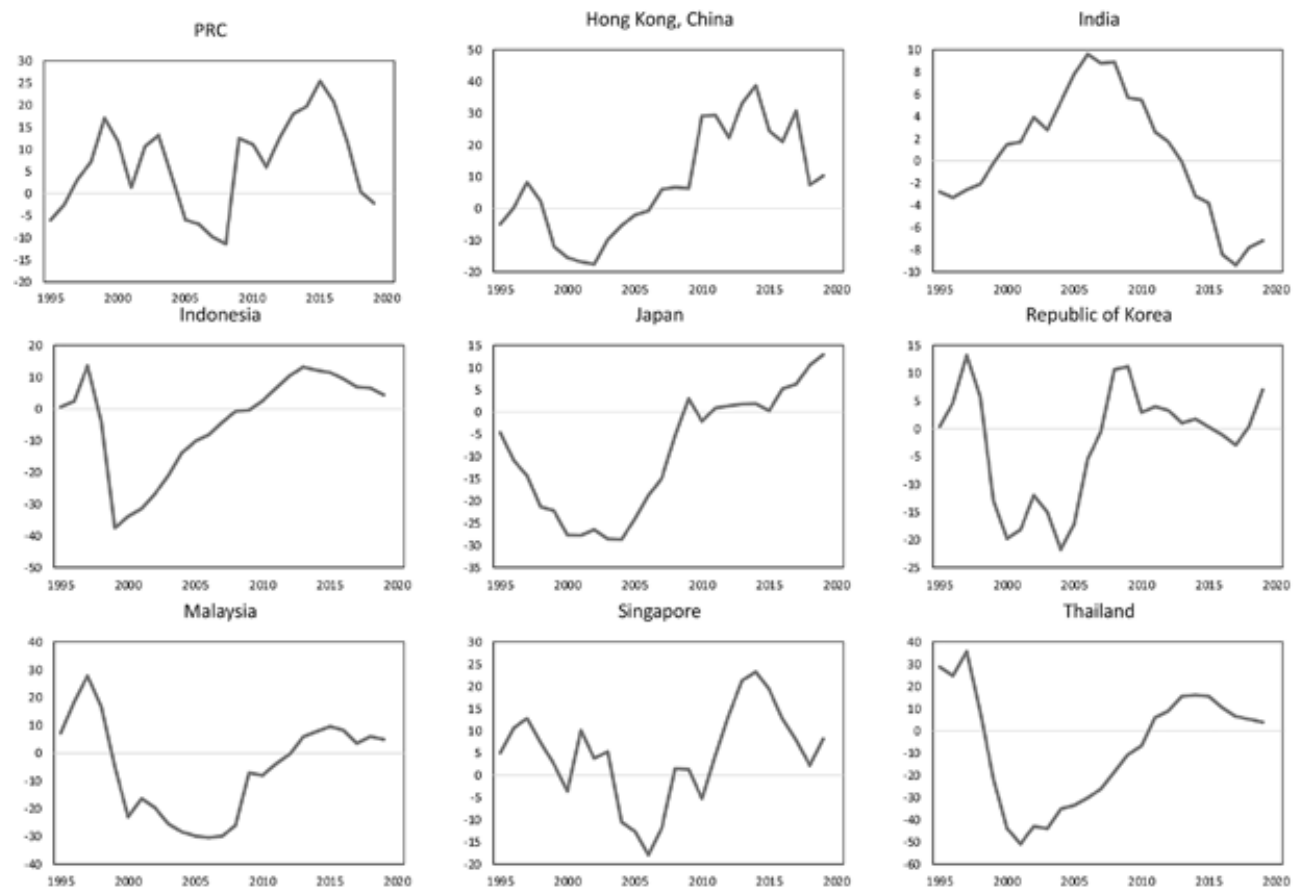

Note : BIS = Bank for International Settlements; GDP = gross domestic product; PRC = People's Republic of China. Source: BIS Statistics.

\section{Figure $8.3 \quad$ Basel Credit Gap (\% of GDP)}

\section{ECONOMETRIC MODELS}

Using two different approaches, this section explores the relationship between household debt and macroeconomic variables. First, we employ an unbalanced panel VAR to highlight a systematic empirical relation between household debt and fluctuations in the business cycles. Second, we implement a micro-simulation model from household survey data to assess household financial vulnerability and its exposure to macroeconomic shocks.

\subsection{Panel Vector Autoregression Model}

This section investigates the relationship between household debt and the magnitude of economic downturns. Following Mian et al. (2017), we estimated a panel VAR model over three variables: household debt-to-GDP, firm debt-to-GDP, and the log real GDP. Our sample includes annual observations from 2001 to 2019 for nine Asian economies: Hong Kong, 
China; the PRC; India; Indonesia; Japan; the ROK: Malaysia; Singapore; and Thailand. ${ }^{6}$ The model estimates the impulse response functions with a local projection estimator, which has become an increasingly widespread alternative econometric approach. ${ }^{7}$ See Jordà (2005).
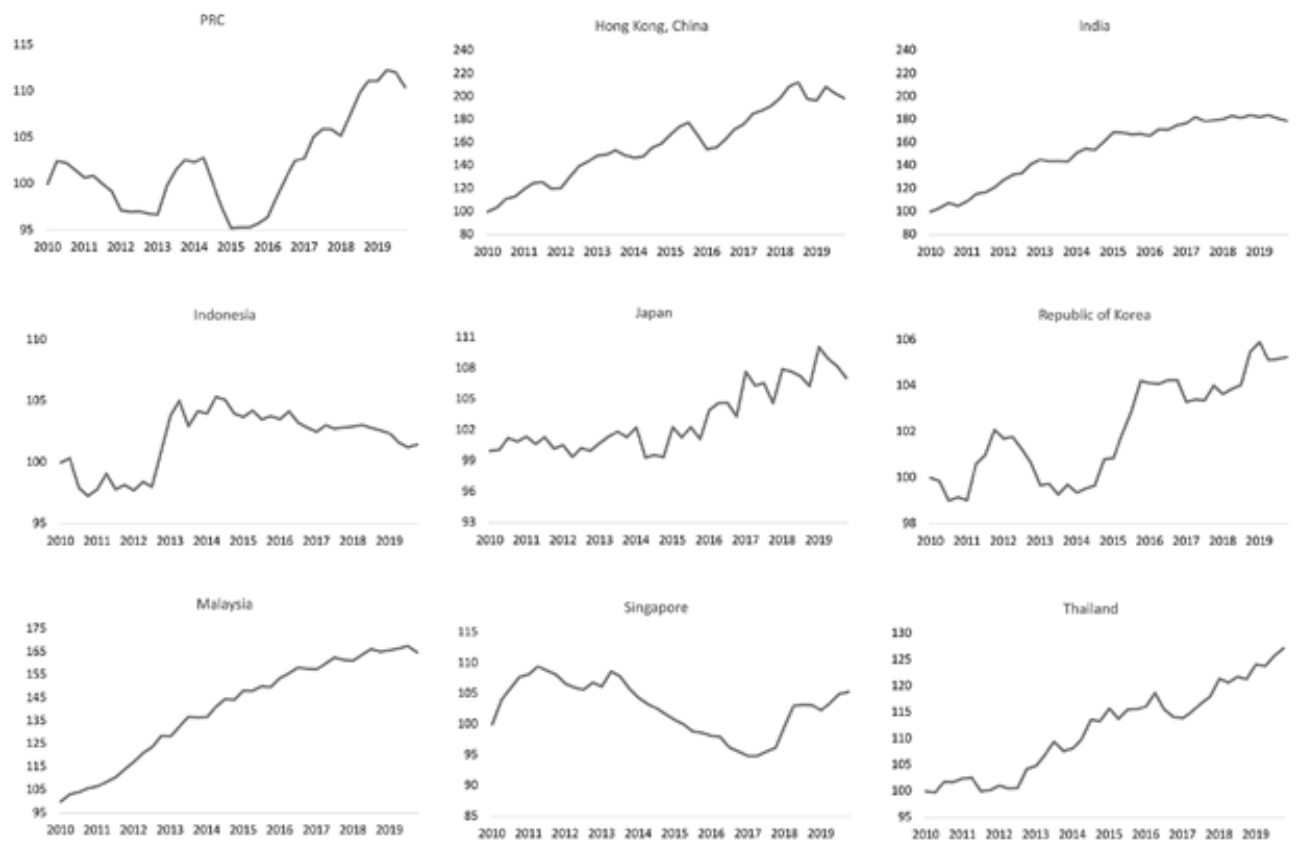

Note $:$ BIS = Bank for International Settlements; PRC = People's Republic of China.

Source: BIS Statistics.

Figure $8.4 \quad$ Real house price index $(2010=100)$

The panel VAR model is given by the following system:

$$
Y_{i, t}=\left\{\ln \left(R G D P_{i, t}\right) ; \frac{H H D_{i, t}}{R G D P_{i, t-1}} ; \frac{N F D_{i, t}}{R G D P_{i, t-1}}\right\},
$$

where $R G D P$ is the real GDP, $H H D$ is the level of household debt, and $N F D$ is the level of nonfinancial firm debt. As in Mian et al. (2017), to avoid capturing innovations to GDP in the debt functions, the debt variables are normalized by the previous annual GDP. Moreover, the estimates include a time trend to prevent the ratio of debt to GDP from reflecting the change in GDP growth and the expansion in the level of debt that many economies have been experiencing. For the sake of comparison, we present estimates for an unbalanced panel across 30 mostly advanced economies over the sample period from 1960 until 2012, as developed by Mian et al. (2017). The results show that an increase in household debt leads to an initial expansion in GDP for about two years (Figure 8.5). After that, it reverses and becomes 
negative in the medium term. Conversely, the GDP response to firm debt is negative in the short term, only reverting to positive after five years. ${ }^{8}$ Mian et al. (2017) concluded that a rise in the household debt-to-GDP ratio over a three- to four-year period predicts a decline in economic growth.

Panel A: GDP Responses after Household Debt Shock

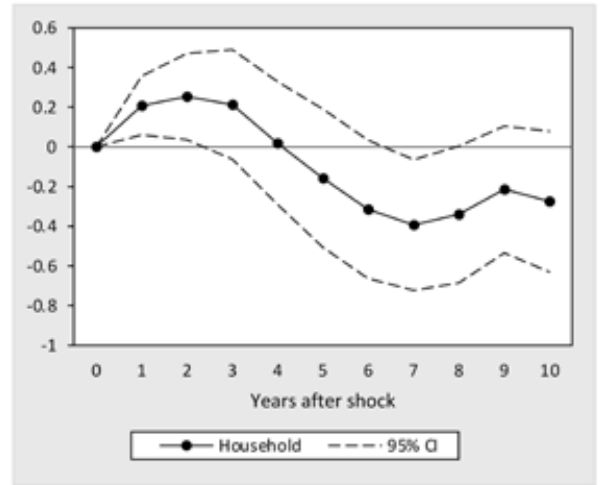

Panel B: GDP Responses after Firm Debt Shock

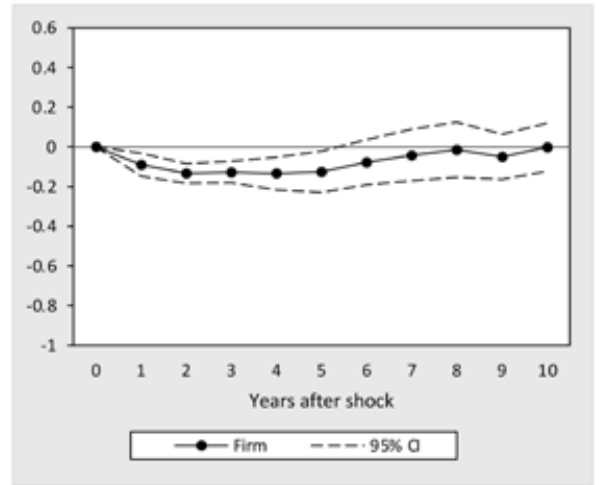

Note: $\mathrm{CI}=$ confidence interval; GDP $=$ gross domestic product. Sources: Author's calculations and Mian et al. (2017).

Figure 8.5 Local projection impulse responses (sample size: 30 economies; sample period: 1960-2012)

Panel A: GDP Responses after Household Debt Shock

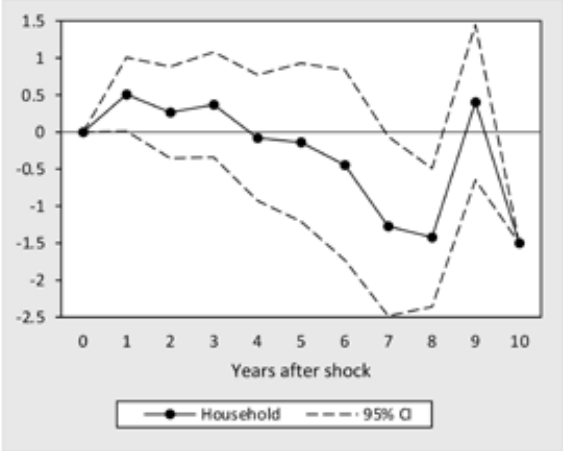

Panel B: GDP Responses after Firm Debt Shock

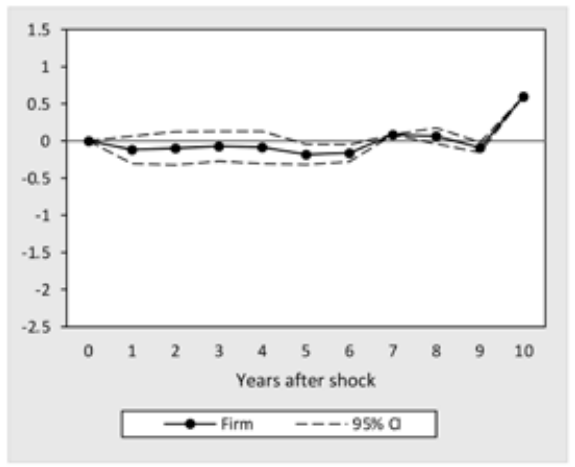

Note: $\mathrm{CI}=$ confidence interval; GDP $=$ gross domestic product.

Source: Author's calculations and Mian et al. (2017).

Figure 8.6 Local projection impulse responses (sample size: nine Asian economies (Asia-9); sample period: 2001-2019) 
Turning to our sample of nine Asian economies (Asia-9), an increase in household debt initially increases real GDP, but such an increase is very short-lived, as real GDP starts declining after one year (Figure 8.6). Asia-9 shows that three years after the initial shock (i.e., the increase in debt), the real GDP returns to the same level at which it was before the shock. For four to eight years after the original shock, the real GDP continues to decline to very low levels. ${ }^{9}$ Comparing our results with those of Mian et al. (2017), we note that Asia-9 shows an increase in GDP by 0.5 percent, while the sample of advanced economies predicts an increase in GDP of 0.2 percent after two years. Moreover, while the larger sample predicts an economic downturn between five years and seven years for a decline of about 0.4 percent in GDP, Asia-9 predicts a larger GDP decline of about 1.5 percent after seven to eight years. In contrast, a shock to firm debt-to-GDP ratio leads to a short- and medium-run decline in GDP, but it is statistically insignificant (Figure 8.6, right panel). ${ }^{10}$ These results confirm the findings of IMF (2017), which show that household debt enhances economic growth in the short term but exacerbates macroeconomic and financial stability risks in the medium term.

The opposite effect of household debt-to-GDP ratio on GDP can be due to a combination of demand and credit shocks. On the one hand, demand shocks allow households to boost consumption, expanding the aggregate demand in the short term. On the other hand, firms respond to the larger aggregate demand by investing and producing more and making an impact on labor productivity and employment in the longer term, thus affecting households' decisions relating to mortgage loans. The next section investigates the credit supply side in more detail.

\subsection{Credit Supply Shock Model}

The results discussed in the previous section may raise concerns pertaining to the identification of the shock. Increases in household debt driven by credit demand shock would boost consumption in goods and dwellings, just as expansions in household permanent income, population growth, or optimistic expectations about house price growth would stoke household borrowing. Nevertheless, household debt shock leads to a short-lived economic expansion, which is a cause for concern when identifying demand- or supply-driven household debt shock (Figure 8.6).

Against this background, this section explores the relative importance of credit supply shocks on the rise in household debt. Credit supply shocks refer to a situation in which banking deregulation allows a larger supply of loans or banks lower the interest rate on mortgage loans. ${ }^{11}$ For example, in 2014 the Government of the ROK drastically eased real estate regulations, raising the loan-to-value (LTV) ratios (solvency requirement) from 50 percent to 70 percent $(20 \mathrm{pp})$ and the debt-to-income ratios (affordability requirement) from 50 percent to 60 percent (10 pp). As a result, expectations of higher housing prices stimulated housing demand as a source of investment.

We used a residual regression from the VAR model to explore the importance of interest rates during the household debt cycle and assess how credit supply expansion leads to household debt cycles and business cycle fluctuations. Following Mian et al. (2017), we first estimate the reduced-from VAR residuals from the previous section with the ordinary least squares (OLS) regression method; and second, we regress the residuals from the household debt-to-GDP equation on the mortgage-sovereign spread, which is expressed as the difference between the mortgage interest rate and the 10-year government bond yield. 
Table $8.2 \quad$ Supply shocks ${ }^{a}$

\begin{tabular}{lcccc}
\hline & \multicolumn{2}{c}{ Panel A } & \multicolumn{2}{c}{ Panel B } \\
\hline & \multicolumn{2}{c}{ Sample: 30 economies } & \multicolumn{2}{c}{ Sample: Asia-7 } \\
\hline \multirow{2}{*}{ MS spread } & HHD_GDP & NFD_GDP & HHD_GDP & NFD_GDP \\
& $-0.341^{* *}$ & -0.0182 & $-1.5235^{* * *}$ & $-2.5419^{* *}$ \\
F-statistics & $(0.101)$ & $(0.267)$ & $(0.5732)$ & $(1.227)$ \\
$R^{2}$ & 11.372 & 0.005 & 7.21 & 4.37 \\
Observations & & & .071 & 0.073 \\
\hline
\end{tabular}

Notes:

HHD GDP = household debt-to-GDP; MS = mortgage-sovereign spread; NFD GDP = firm debt-to-GDP.

Panel A reproduces estimates from Mian et al. (2017). Panel B reports estimates from the Asia-7 sample, which includes Hong Kong, China; Indonesia; Japan; the Republic of Korea; Malaysia; Singapore; and Thailand.

$*, * *$, and $* * *$ indicate significance at the $0.1,0.05$, and 0.01 levels, respectively.

a MS data for the People's Republic of China and India are available only for a very short period, and thus have been removed from the estimation.

Sources: Author's calculations; and Mian et al. (2017).

The negative coefficients in panels A and B in Table 8.2 indicate that much of the variation in household and firm debt is explained by a low interest rate environment. This result supports the argument that mortgage spreads are correlated with outward shifts in credit supply, rather than in credit demand. Moreover, such correlation is much stronger in Asian economies relative to advanced economies: Mian et al. (2017) estimated a negative correlation between the mortgage-sovereign spread instrument and the household debt for 30 advanced economies equal to -0.341 , while the sample of seven Asian economies reported a coefficient of -1.5235 , indicating a larger magnitude when focusing only on the Asian region. The slower economic growth of the last decade has been coupled with ultra-low inflation and policy rates. In general, a low interest rate environment can lower the debt service burdens of households, helping them to be solvent. Further, asset prices tend to rise when interest rates are low, thus increasing the collateral value and making households more creditworthy for banks. Such effect will amplify the credit cycle. However, as already mentioned, such a positive effect is short-lived across Asian economies and would lead to economic recession in the longer term. If this occurs, lower income will preclude households from servicing their mortgage obligation despite the low interest rates, aggravating the recession even more and causing prolonged bust phases. Furthermore, the persistence of low interest rates pushes the household debt-to-GDP ratio to rise even further, leading to sustainability risk. This research shows that the expansion in household debt has been mainly supply-driven (i.e., lending expansion by financial institutions and low interest rates), rather than demand-driven (i.e., higher productivity or a permanent increase in household incomes). This result corroborates the hypothesis that sustainability issues escalate when the expansion of credit is not accompanied by a similar expansion in income. 


\subsection{Survey Data-Macro Stress Test}

An analysis based on aggregate data is not sufficient to gauge the sustainability of household debt; a proper analysis using micro data is needed to complement it. This section gives an outline of a micro-simulation model for stress testing the household sector in the PRC and the ROK. The model uses data from the China Family Panel Studies, which covers surveys in 2014 and 2016, and data from the ROK's Labor and Income Panel Study (KLIPS) from 2015 to $2018 .^{12}$

This model captures the debt-repayment capacity of households and assesses the financial resilience of the household sector to COVID-19 shocks, such as a sudden decrease in disposable income. To assess the soundness of the financial system, it is important to evaluate the households' default risk based on their characteristics and thus assess their vulnerability by income group.

Following Funke et al. (2018), the model builds a financial margin (FM) indicator for the household liquidity condition. The FM is defined as:

$F \mathbf{M}=\boldsymbol{Y}-\boldsymbol{C}-\boldsymbol{D S}$,

where $Y$ denotes household disposable income, $C$ is household consumption, and $D \mathrm{~S}$ is debt service. These variables are measured annually.

We define the condition in which households default on their debt as a situation in which they lack sufficient semi-liquid or liquid assets to sell to repay their debts. Unlike real estate assets, liquid financial assets are typically easy to sell and are subject to lower haircuts and, hence, could serve as a short-term buffer against unanticipated adverse shocks to disposable income. Since the KLIPS surveys do not provide a breakdown of liquid assets and nonliquid assets, we use nonhousing assets as a proxy to measure for liquid assets. ${ }^{13}$

Following Funke et al. (2018) and Han et al. (2019), households would default on their debt if the following extended financial margin (EFM) condition is satisfied:

$F M<0$ and $F M+L A<0$,

where $L \mathrm{~A}$ denotes liquid assets. Thus, the default condition follows a situation where households have insufficient liquid assets to cover the negative FM.

When the EFM condition is satisfied, then the probability of default $(\boldsymbol{P D})$ is equal to 1, otherwise zero:

$$
P D=\left\{\begin{array}{c}
1, \text { ifFM }<0(F M+L A)<0 \\
0, \text { otherwise }
\end{array}\right.
$$

Figure 8.7 reports the share of households with a negative FM and insufficient liquid assets to cover the FM. In the PRC in 2014, around 30 percent of households with negative FM belonged to the first quintile, that is, they had the lowest income share. This share increases slightly in the following years. About 25 percent of the second income quintile also has a negative EFM condition, which likewise decreases over time. In the highest-income quintile, the model predicts that 11 percent of households would have a negative FM and insufficient 


\section{Panel A: People's Republic of China}

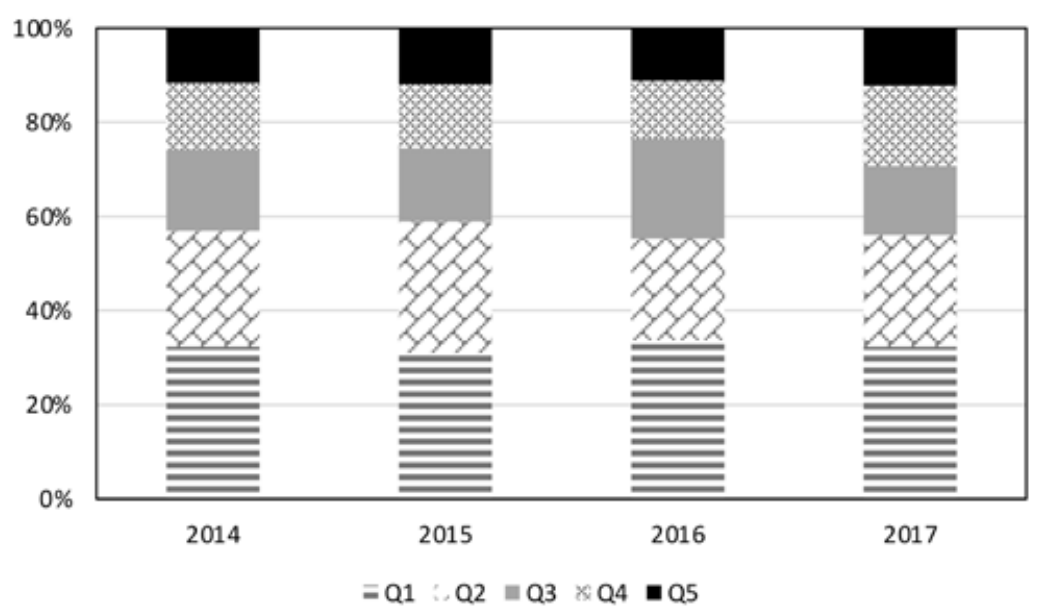

\section{Panel B: Republic of Korea}

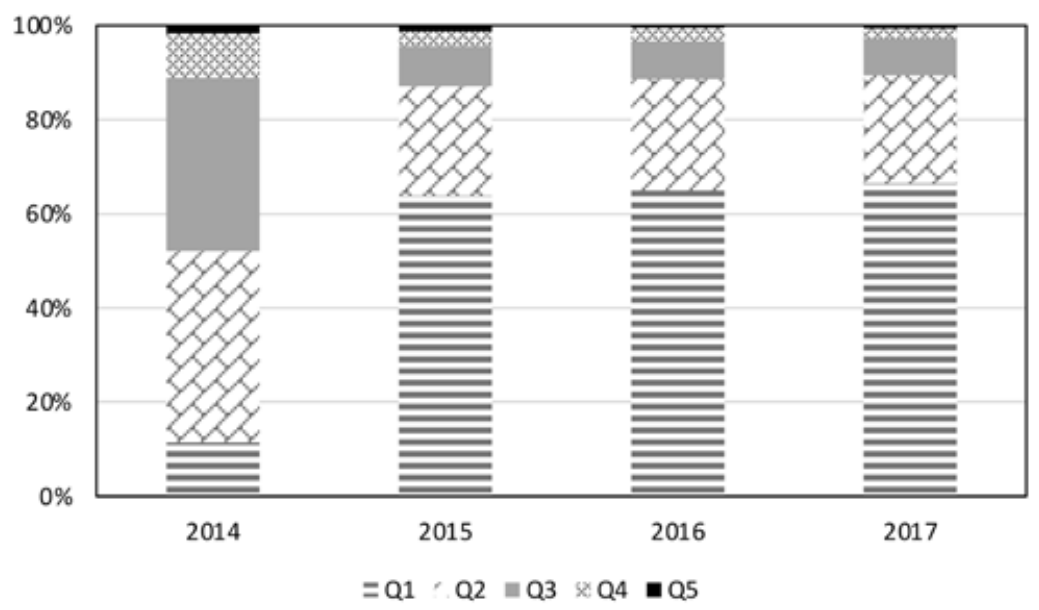

Note: $\mathrm{EFM}=$ extended financial margin; $\mathrm{Q}=$ quarter.

Sources: China Family Panel Studies (CFPS); Republic of Korea's Labor and Income Panel Study (KLIPS); author's calculations.

\section{Figure 8.7 EFM condition by income quintile}

liquid assets. In the ROK, however, around 65 percent of the first income quintile group satisfies the EFM conditions, and a very small share belongs to the third, fourth and fifth income groups. Like the PRC, around 23 percent of the second income quintile has a negative FM. Interestingly, in 2015 , only 10 percent of the first income quintile had a negative FM, while 
a sizable share is held by the second and third income quintile, with a share of 40 percent and 37 percent, respectively. Naturally, the risk of default falls in both economies as income level rises. But it falls from much higher levels in the PRC.

Panel A: People's Republic of China

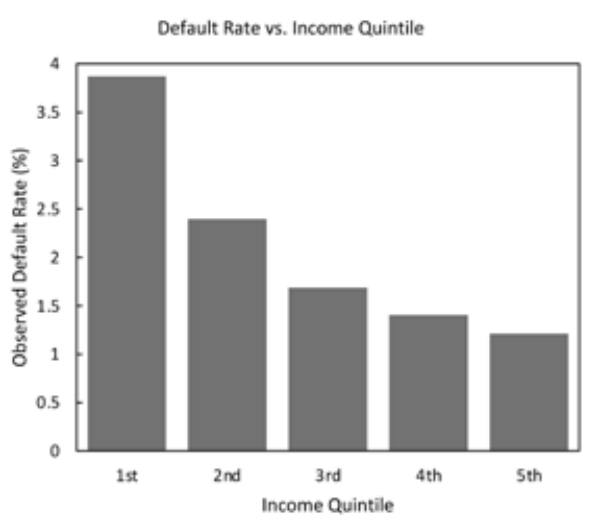

Note: Average across the years of survey. Source: Author's calculation.
Panel B: Republic of Korea

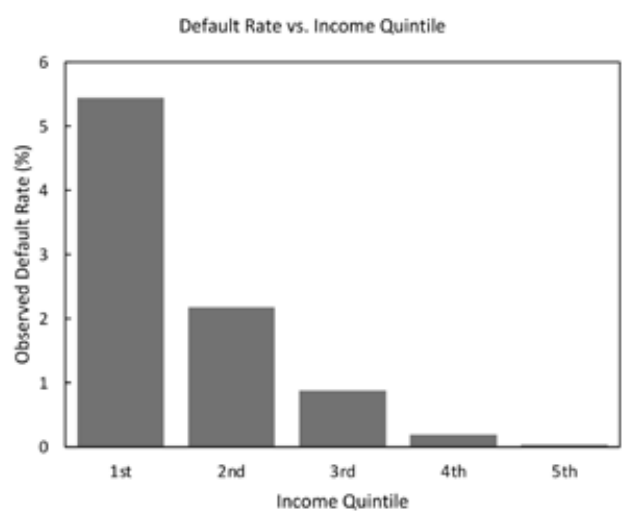

\section{Figure $8.8 \quad$ Observed default rates}

Figure 8.8 shows the observed averaged default rate calculated from the EFM conditions by income quintile. The share of indebted households with negative financial margins tends to decrease with higher disposable income. The ROK observes a default rate higher than 5 percent and 2 percent for the first and second income group, respectively, while the default rate is lower than 1 percent for the other income quintiles. ${ }^{14}$ On the other hand, the PRC reports higher default rates for all income groups; however, the first income quintile reports a default rate of almost 4 percent, lower than the ROK. The default rate resolved by income class can be indicative of the capability of households to sustain the current situation and future shocks. There is no benchmark value for the default rate. However, for instance, Luxembourg in 2014 showed a default rate of about 9.3 percent for the first income quintile, ${ }^{15}$ and was deemed by the European Systemic Risk Board (ESRB 2016) to have medium-term vulnerability, based on this result and some other estimates. In the ROK, about 60 percent of indebted households are in the lowest-income quintile. Worryingly, their financial margin is not only negative, but this income class does not hold sufficient liquid assets to meet their loan obligations. Indeed, the lowest-income class reports a default rate of about 5.5 percent. Higher-income classes, instead, show a very low probability of default. Even if the Korean default rate is not as high as in the case of Luxembourg, the high level of household debt-to-GDP and the slowing economic growth are reasons for concern. In contrast, survey data show that in the case of the PRC, the default rates are much higher across all income classes. However, the debt burden has worsened much faster for low-income households, making them more vulnerable to unfavorable income shocks. Even if the household debt-to-GDP is not as high as in the ROK, the much 
higher growth of the indebtedness level relative to other economies makes the high default rate problematic.

\section{Panel A:}

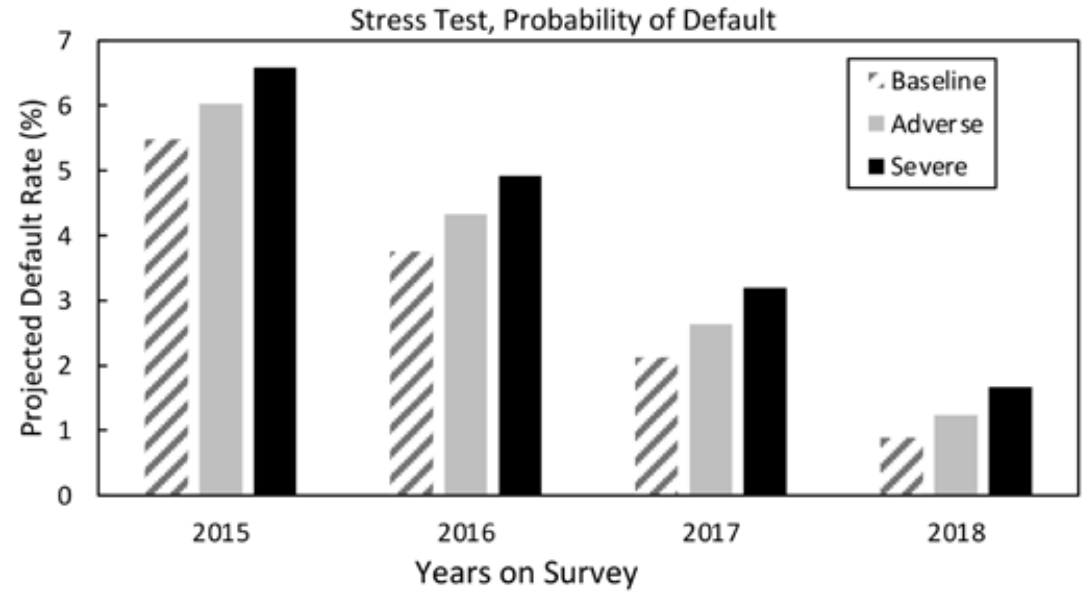

\section{Panel B:}

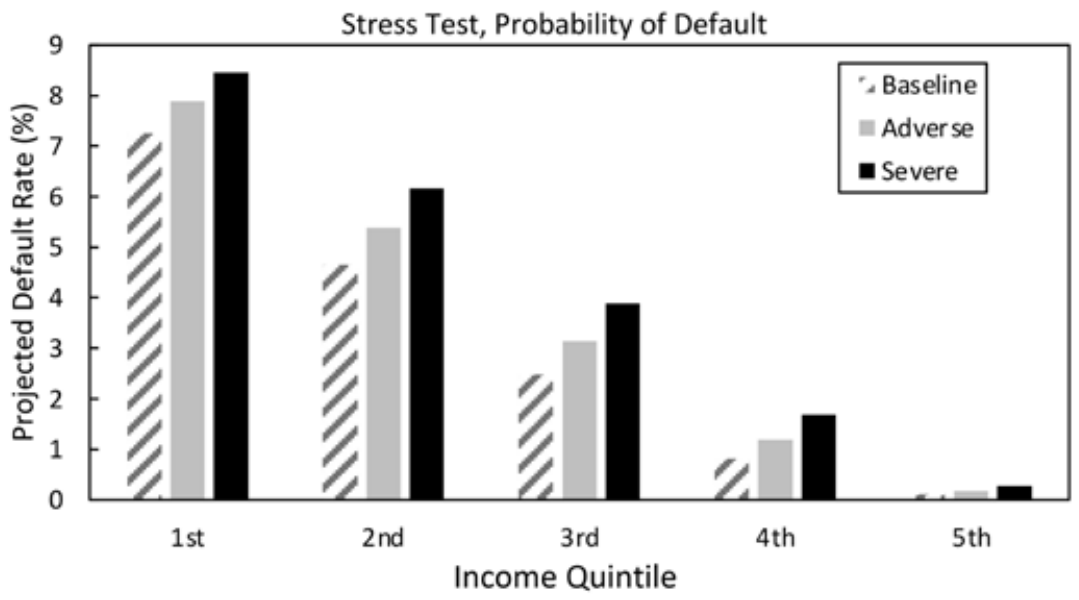

Source: Author's calculation.

Figure 8.9 Republic of Korea-stress test

After constructing the probability of default from the EFM condition, the model evaluates the financial resilience of the household sector to macroeconomic shocks. From the survey data, we construct a panel dataset of mortgage loans to identify default rate patterns for loans 


\section{Panel A:}

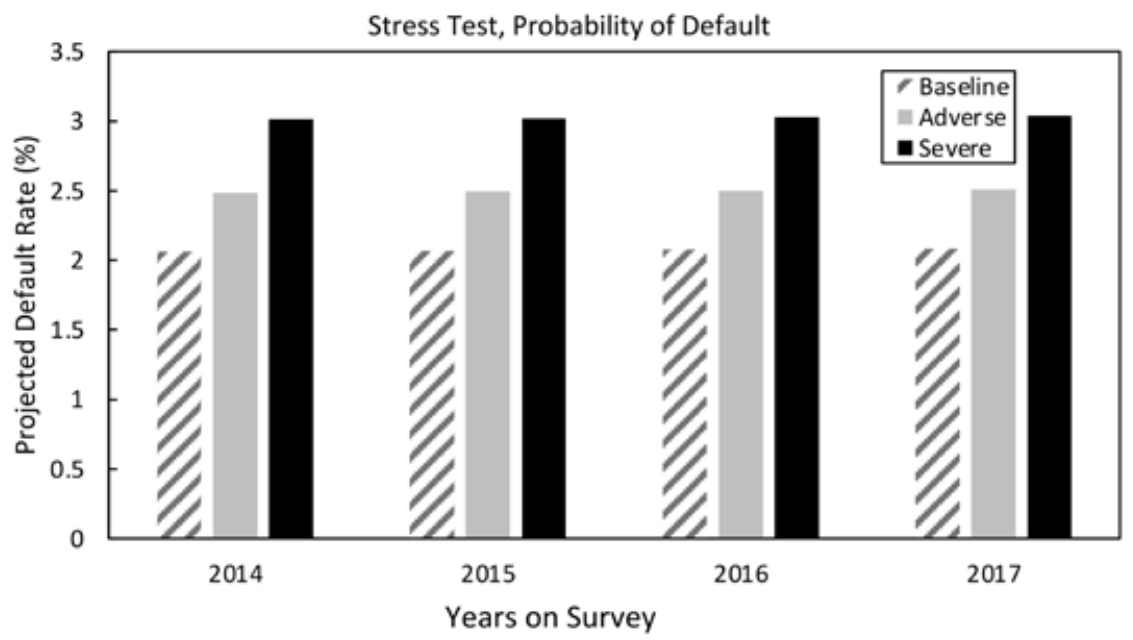

Panel B:

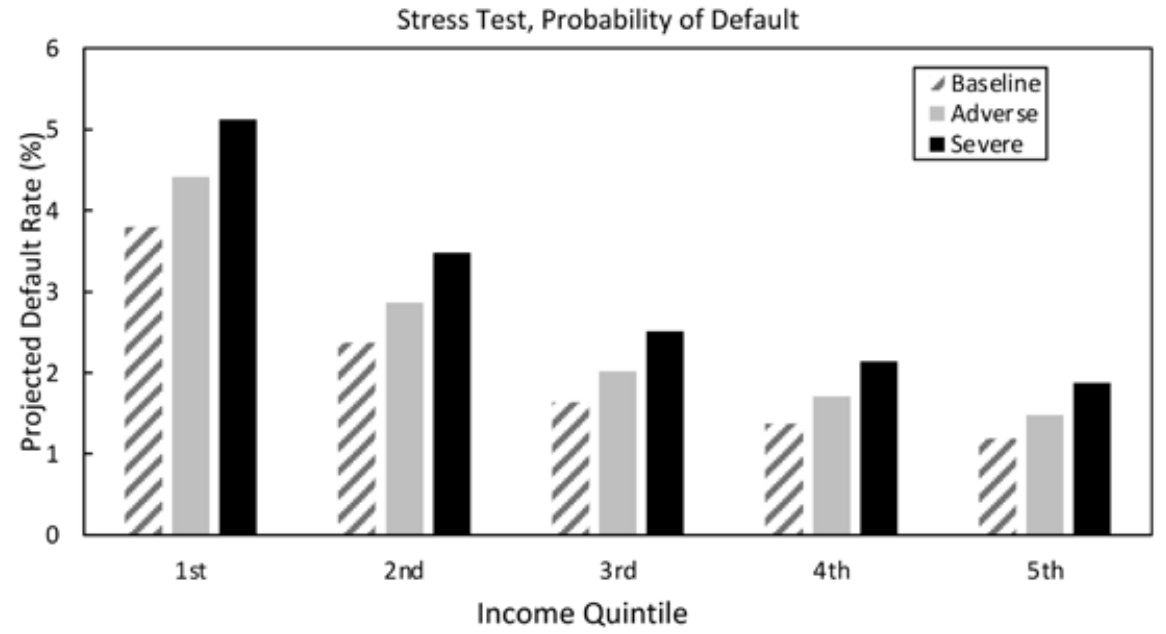

Source: Author's calculation.

Figure $8.10 \quad$ People's Republic of China-stress test

of different income levels. Thus, information can be derived about the income quintile to distinguish default rates for different income levels, using the "logistic regression" model to make predictions.

The macro stress simulates an adverse shock equal to a 5 percent decline in household income, and a severe shock equal to a 10 percent decline. Despite the large increase in house- 
hold debt-to-GDP, the ROK reports a declining predicted default rate across all households (Figure 8.9, panel A). Negative shocks to income lead to higher probability of defaults, as lower income would impact a household's ability to repay mortgage loans. This is a possible impact of the COVID-19 pandemic and consequential lockdowns, where many households with less income and higher unemployment would find it harder to meet mortgage payments. In terms of income groups, households belonging to the first three income quintiles appear to be more sensitive to changes in disposable income. The second income group is slightly more vulnerable to income changes relative to the first income group. This is most likely because the second income quintile held a larger share of negative EFM in 2015. The fourth and fifth quintile groups are only marginally affected (Figure 8.9, panel B).

Unlike the ROK, the data predict similar default rates year on year for the PRC. A decline in income would lead to an increase in the default rate by about 20 percent, while larger income drops of 10 percent would generate an increase of about 45 percent. Thus, there is an amplified effect to the sensitivity of income shocks (Figure 8.10, panel A).

Across income classes, the first quintile would experience an increase in the default rate of about 15 percent and 30 percent for the adverse and severe scenarios, respectively (Figure 8.10 , panel B). It is worth noting, however, that the other income classes also report an increasing default rate, indicating that income shocks affect the vulnerability to repay loans in equal measure across households. In contrast, income shocks in the ROK are most likely to affect only lower-income holders.

\section{POLICY RESPONSE}

Since the GFC, macroprudential policy has been used as a powerful tool to lean against credit and housing cycles. Even if the economic and financial impact is still controversial, policies which aim to slow down household debt, such as caps on the LTV ratio that would limit mortgages, would give central banks more space to stabilize the economy. ${ }^{16}$

Since 2000, many Asian economies have introduced caps on the LTV ratio to limit the growth in household debt (Figure 8.11). The PRC has been strengthening its implementation of various macroprudential measures since 2009. In 2015, it set new indicators for assets, leverage and debt, and strengthened the management of its cross-border capital flows; and in 2016, it imposed caps on the LTV for residential property. Macroprudential measures have also been in place for a long time in the ROK and have been gradually strengthened to include caps on the maximum LTV and DSTI ratios and on the maximum repayments-to-income ratio for mortgages, limits on the LTV ratio for commercial business, and limits on debt-to-service for the nonbanking sector. However, the PRC; India; Indonesia; the ROK; and Taipei,China have experienced increased household debt growth from 2014 to 2016. The notable increase in household debt over the past years has demonstrated that perhaps LTV tightening measures are insufficient to mitigate the problem.

The LTV ratio is the most effective policy tool that the financial regulation authority can use to dampen the mutually reinforcing dynamics of housing credit and prices. However, as this ratio can be underestimated, macroprudential authorities should implement complementary tools to enhance the effectiveness of macroprudential policies. With this in mind, Finland in 2018 introduced a new macroprudential tool, the maximum loan-to-collateral ratio, to be applied instead of the LTV ratio. The loan-to-collateral ratio differs from the LTV, as it takes 

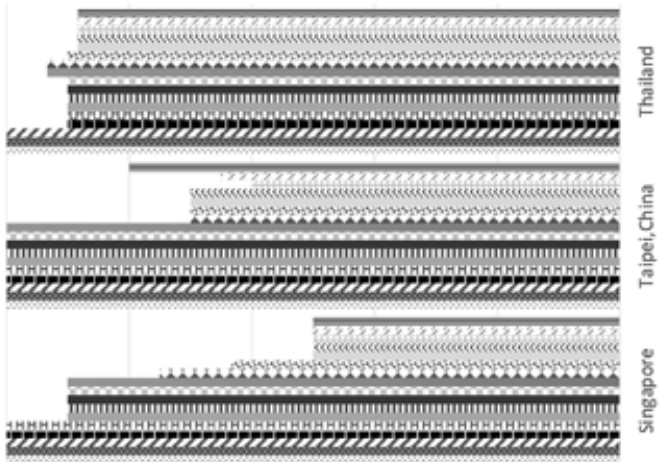

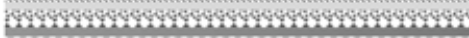
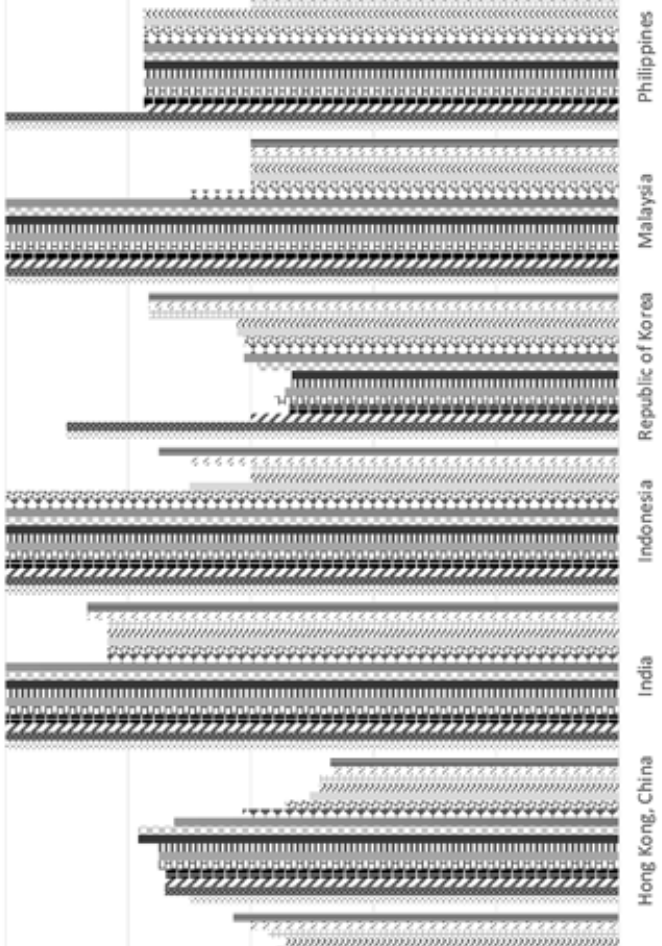

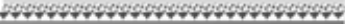
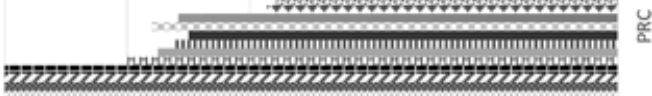

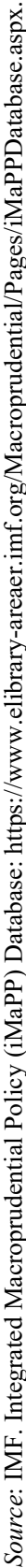

$\therefore$ 
into account the borrower's house collateral and all the other collateral accepted by the lender. This new macroprudential tool is effective in reducing growing household indebtedness by restricting the provision of mortgage loans relative to collateral. It should be considered as an alternative tool to be implemented in economies experiencing rapid growth in household debt.

The central bank of the Philippines (BSP) supervises the operations of banks and nonbank financial institutions performing quasi-banking functions and those performing similar functions. In particular, the BSP compiles a Manual of Regulations for Non-Bank Financial Institutions, which incorporates regulatory policies to align banking practices on risk management; good corporate governance; and capital adequacy, accounting and reporting using international standards.

\section{CONCLUSIONS AND POLICY RECOMMENDATIONS}

The analysis of this chapter has shown that a rising household debt-to-GDP ratio boosts economic growth in the near term but increases the risk of low economic growth over the medium term. Using a sample of nine Asian economies, we find that an increase in the ratio of household debt increases real GDP by 0.5 percent, but this positive effect reverts after seven years to a decline of 1.5 percent. While a certain degree of heterogeneity is present, all nine economies are sensitive to changes in credit supply and house prices.

This study also gauges the vulnerability of household debt when the economy is subject to an unexpected decrease in income due to reduced working hours, furloughs, and outright unemployment during the COVID-19 pandemic and finds that in the PRC and in the ROK, the bottom 20 percent of the household income distribution is most likely to default on their mortgages. However, while the probability of default for the upper-income households is marginal in the ROK, findings indicate that in the PRC all income groups would be more likely to default, even if the probability decreases with higher income.

Household indebtedness has been on the rise in many Asian economies since 2010, jeopardizing future economic growth and the soundness of the financial system. Some central banks and policy makers have been raising concerns over high and/or rising levels of household debt, which is driven mostly by mortgages. Rising household debt has consequences for both economic and financial stability. On the one hand, economic stability can be compromised as interest rates have asymmetric effects on households with high debt levels. Indeed, the economic contraction resulting from an interest rate hike would be larger than the expansionary effect an interest rate cut would generate. On the other hand, financial stability can be compromised as some households, through loss of income, could limit their ability to pay off existing debts and thus find themselves in severe financial stress. The combination of these effects could put pressure on banks' balance sheets.

In terms of policy implications, households respond differently to shocks, depending on their savings and on the mortgage market, as well as on whether they have a fixed or variable mortgage rate, of which the latter makes them more vulnerable to interest rate hikes or changes in income. The macroeconomic effect, though, remains ambiguous, as some households can respond to negative shocks by cutting consumption or by borrowing more, unless their debt level is already too high.

Macroprudential tools can play a better role in preventing the accumulation of financial risks and strengthening the financial system's resilience if integrated with stricter loan 
appraisal regulations. In addition, low-income households with bad credit or multiple loans (i.e., low credit ratings) shift their loan demands to the nonbanking sector that would then charge higher interest rates. To guarantee financial stability, it is very important to regulate nonbank financial institutions.

Fiscal policy can also play a role if combined with monetary and macroprudential policies. For instance, policies that aim to reduce the tax deductibility of mortgage interest rates and tighten regulatory LTV ratios would be far more effective in dampening household debt and thus reducing macroeconomic risks. Reducing tax deductibility of mortgage interest rates would lead to a decline in borrower mortgage demand and subsequently cause housing prices to fall. However, savers and high-income households could take advantage of lower housing prices, increasing their housing demand and returning housing values to where they were before the introduction of this fiscal policy.

Finally, communication strategies, timing and coordination are very important to mitigate the buildup of systemic risks. Timely coordination between macroprudential and monetary policy would benefit both macroeconomic and financial stability, as macroprudential tools in the short term would allow central banks to stabilize the economy in the medium term. Thus, macroprudential policies today can help monetary policy tomorrow, particularly in periods of low interest rate environment.

The household debt problem could be exacerbated in 2020 as personal income and business revenue suffer from the outbreak of the COVID-19 pandemic. Although policy makers have made extraordinary efforts to create a series of emergency credit facilities to support growth and provide relief for vulnerable groups, the COVID-19 pandemic and consequential lockdown will affect households through various direct and indirect channels. Lack of tourism, mobility restrictions, adverse health, seized working hours, furloughs, and outright unemployment will directly affect households through loss of income, limiting their ability to service existing debts and thus exacerbating the severity of their financial stress. Moreover, households may be forced to borrow more to survive the weaker and more protracted recovery, thus escalating the risk of financial instability in the future.

Many economists have described the COVID-19 pandemic as an "induced economic coma" and they expect to be looking at a V-shaped economic recovery. However, this line of thinking focuses only on the reopening of businesses without considering the impact on household debt and its negative spillover effect to the rest of the economy. Households are already falling behind on debt repayments and are cutting their consumption expenditure, contributing to a prolonged recession. However, debt service by borrowers is expected to improve in jurisdictions with adjustable mortgage rates, and persistent low interest rates will support the economic recovery, reducing the risk that income loss will be long-lasting.

It is important to coordinate some re-distributional intervention. For example, some losses from debt-repayment moratoriums occurring during the lockdown should be transferred from vulnerable households to banks or lenders. Alternatively, current debt burdens could eventually be transferred to future taxpayer generations by current government interventions aimed at alleviating low-income households' balance sheets. In addition, it is important to temporarily relieve low-income households from financial burden by extending the repayment period and converting high-interest debt into lower interest.

Although there are no benchmark values to label an economy at risk based on household debt indicators, policy makers should carefully assess if the expansion in household debt is 
supply- or demand-driven. This determination should inform the design of a well-coordinated mix of policies to mitigate over indebtedness in normal times. In difficult times, such as during the COVID-19 pandemic, many governments have introduced heavy fiscal stimulus packages for safeguarding households facing income loss such as unemployment benefits, salary subsidies, and delayed moratoriums on tax payment. However, particular attention should be given to households in the lowest-income quintile and risk assessment measures should be implemented by considering the borrowers' distribution in terms of their ability to service their debt.

\section{NOTES}

1. The views expressed therein are those of the authors and do not necessarily reflect the views and policies of ADB, its Board of Governors or the governments they represent. The author thanks Benno Ferrarini, Marcelo Giugale, and Juan Pradelli for their insightful comments; Marco Battiato for his coding support in Matlab; and Anastasiia Hizenko for excellent research assistance.

2. See Valckx (2017).

3. Similarly, the level of debt as a percentage of GDP, borne by households in 2007 in Australia, New Zealand, and the United Kingdom has increased gradually to 110 percent, 91 percent and 92 percent, respectively, with an increase since 2000 of around 30-40 pp. Between 2000 and 2007, all these economies reached a much higher ratio than the average value within the euro area as well as the average value among advanced economies, which stood at 60 percent and 82 percent in 2007 , respectively.

4. See Illing et al. (2018); Justiniano et al. (2019); Cecchetti and Kharroubi (2019); and Mian et al. (2020).

5. See Bernanke et al. (1999); Iacoviello (2005); and Iacoviello and Neri (2010).

6 The dataset is an unbalanced panel data. For instance, observations on household debt-to-GDP for the PRC and Malaysia start from 2006, and for India the sample starts from 2007.

7. Plagborg-Møller and Wolf (2019) have proved that local projections and VARs estimate similar impulse response functions.

8. Similar results are found in Park et al. (2018).

9. Mian et al. (2017) showed that increasing household debt is associated with increasing consumption-to-GDP ratio, a rise in imports of consumption goods, but no change in the investment-to-GDP ratio.

10. Chapter 7 finds that corporate debt increases tend to reduce output growth, contributing to financial deterioration. Exceptions are the PRC, the ROK, Japan, and Malaysia, whereas output growth accelerates when corporate debt-to-output ratio increases.

11. According to Mian and Sufi (2018), banking deregulation is assumed to be unrelated to variations in GDP or households' income.

12. The China Family Panel Studies contains information pertaining to 26683 households that participated in surveys conducted in 2014 and 2016, while KLIPS contains information pertaining to a total of 28102 households over the period 2015-2018.

13. The use of nonhousing assets as a proxy for liquid assets could overestimate households' liquid assets (for example, some nonhousing assets, such as cars, are less liquid and subject to higher haircuts in liquidation); and hence, households could actually start to default before they deplete all their nonhousing assets.

14. Kim et al. (2016) found that in 2014 the default rate by income quintile was 3.5 percent, 3.7 percent, 3.3 percent, 2.7 percent, and 1.4 percent, indicating that high-income groups tend to have lower default rates and better credit scores.

15. See Giordana and Ziegelmeyer (2020).

16. Some studies analyze boom and bust phases of credit cycles and find that peaks and troughs can be contained if macroprudential policies are properly introduced (Dell'Ariccia et al. 2012). Claessens et al. (2013) and Cerutti et al. (2017) showed that borrower-based measures, such as maximum LTV and debt-to-service income (DSTI) ratios, can contain asset and leverage growth in good times, but they do not limit the cost of busts. Kuttner and Shim (2016) found that a lower DSTI 
ratio reduces the real credit growth rate by 4-6 pp over four quarters, and Richter et al. (2019) found that tightening the maximum LTV ratio leads to a reduction in output. Wong et al. (2011) showed how higher LTV caps in Hong Kong, China could have contributed to the decrease of the mortgage debt-to-GDP ratio in the 1990s and 2000s. Tillmann (2015) found that limits to LTV and DSTI can have substantial effects on the ROK's household credit growth.

\section{REFERENCES}

Baba, C., S. Dell'Erba, E. Detragiache, O. Harrison, A. Mineshima, A. Musayev and A. Shahmoradi. 2020. How Should Credit Gaps Be Measured? An Application to European Countries. IMF Working Paper. No. 20/6. Washington, DC: International Monetary Fund (IMF).

Bernanke, B.S., M. Gertler and S. Gilchrist. 1999. The Financial Accelerator in a Quantitative Business Cycle Framework. In J.B. Taylor and M. Woodford (eds), Handbook of Macroeconomics. 1. Chapter 21. pp. 1341-93. Amsterdam: Elsevier.

Cecchetti, S.G. and E. Kharroubi. 2019. Why Does Credit Growth Crowd Out Real Economic Growth?. The Manchester School. 87, pp. 1-28.

Cecchetti, S.G., M.S. Mohanty and F. Zampolli. 2011. The Real Effects of Debt. BIS Working Paper. No. 352. Basel: Bank for International Settlements (BIS).

Cerutti, E., S. Claessens and L. Laeven. 2017. The Use and Effectiveness of Macroprudential Policies: New Evidence. Journal of Financial Stability. 28, pp. 203-24.

Claessens, S., S.R. Ghosh and R. Mihet. 2013. Macro-Prudential Policies to Mitigate Financial System Vulnerabilities. Journal of International Money and Finance. 39, pp. 153-85.

Dell'Ariccia, M.G., M.L. Laeven, J. Vandenbussche, D. Igan, M.B.B. Bakker and H. Tong. 2012. Policies for Macrofinancial Stability: How to Deal with Credit Booms. IMF Staff Discussion Note. No. SDN12/06. Washington, DC: IMF.

European Systemic Risk Board (ESRB). 2016. Warning of the European Systemic Risk Board of 22 September 2016 on Medium-Term Vulnerabilities in the Real Estate Sector of Luxembourg. ESRB/2016/09. Accessed at: https://www.esrb.europa.eu/pub/pdf/warnings/161128_ESRB LU warning.en.pdf?8b66a6785ab61433becd2478eda7deb1.

Funke, M., S. Rongrong and Z. Linxu. 2018. The Credit Risk of Chinese Households: A Micro-Level Assessment. Mimeo.

Giordana, G. and M. Ziegelmeyer. 2020. Stress Testing Household Balance Sheets in Luxembourg. The Quarterly Review of Economics and Finance. 76, pp. 115-38.

Han, M.F., M.E.M. Jurzyk, W. Guo, Y. He and M.N. Rendak. 2019. Assessing Macro-Financial Risks of Household Debt in China. IMF Working Paper. No. 19/258. Washington, DC: IMF.

Iacoviello, M. 2005. House Prices, Borrowing Constraints, and Monetary Policy in the Business Cycle. American Economic Review. 95(3), pp. 739-64.

Iacoviello, M. and S. Neri. 2010. Housing Market Spillovers: Evidence from an Estimated DSGE Model. American Economic Journal: Macroeconomics. 2(2), pp. 125-64.

Illing, G., Y. Ono and M. Schlegl. 2018. Credit Booms, Debt Overhang and Secular Stagnation. European Economic Review. 108, pp. 78-104.

International Monetary Fund (IMF). 2017. Household Debt and Financial Stability. Chapter 2 in Global Financial Stability Report October 2017: Is Growth at Risk. Washington, DC.

Jordà, Ò. 2005. Estimation and Inference of Impulse Responses by Local Projections. American Economic Review. 95(1), pp. 161-82.

Justiniano, A., G.E. Primiceri and A. Tambalotti. 2019. Credit Supply and the Housing Boom. Journal of Political Economy. 127(3), pp. 1317-50.

Kim, Y.I., H.C. Kim and J.H. Yoo. 2016. Household Over-Indebtedness and Financial Vulnerability in Republic of Korea: Evidence from Credit Bureau Data. KDI Journal of Economic Policy. 38(3), pp. $53-77$.

Kuttner, K.N. and I. Shim. 2016. Can Non-Interest Rate Policies Stabilize Housing Markets? Evidence from a Panel of 57 Economies. Journal of Financial Stability. 26, pp. 31-44. 
Leigh, D., D. Igan, J. Simon and P. Topalova. 2012. Dealing with Household Debt. In International Monetary Fund. World Economic Outlook: Growth Resuming, Dangers Remain. Washington, DC. pp. 125-63.

Mian, A. and A. Sufi. 2018. Finance and Business Cycles: The Credit-Driven Household Demand Channel. Journal of Economic Perspectives. 32(3), pp. 31-58.

Mian, A., A. Sufi and E. Verner. 2017. Household Debt and Business Cycles Worldwide. The Quarterly Journal of Economics. 132(4), pp. 1755-817.

Mian, A., A. Sufi and E. Verner. 2020. How Does Credit Supply Expansion Affect the Real Economy? The Productive Capacity and Household Demand Channels. The Journal of Finance. 75(2), pp. 949-94.

Park, D., K. Shin and G. Tian. 2018. Household Debt, Corporate Debt, and the Real Economy: Some Empirical Evidence. Asian Development Bank Economics Working Paper Series. No. 567. Manila: Asian Development Bank.

Plagborg-Møller, M. and C.K. Wolf. 2019. Local Projections and VARs Estimate the Same Impulse Responses. Unpublished paper: Department of Economics, Princeton University, 1.

Richter, B., M. Schularick and I. Shim. 2019. The Costs of Macroprudential Policy. Journal of International Economics. 118, pp. 263-82.

Schularick, M. and A.M. Taylor. 2012. Credit Booms Gone Bust: Monetary Policy, Leverage Cycles, and Financial Crises, 1870-2008. American Economic Review. 102(2), pp. 1029-61.

Tillmann, P. 2015. Estimating the Effects of Macroprudential Policy Shocks: A Qual VAR Approach. Economics Letters. 135, pp. 1-4.

Valckx, N. 2017. Rising Household Debt: What it Means for Growth and Stability. International Monetary Fund Blog. Washington, DC: IMF.

Wong, T.C., T. Fong, K.F. Li and H. Choi. 2011. Loan-to-Value Ratio as a Macroprudential Tool Hong Kong's Experience and Cross-Country Evidence. Working Papers 1101. Hong Kong Monetary Authority.

Zabai, A. 2017. Household Debt: Recent Developments and Challenges. BIS Quarterly Review. December. Basel: BIS. 